\title{
Modelling the Effect of Income and Car Ownership on Recreational Trip in Akure ,Nigeria
}

\section{Article $\cdot$ March 2015}

DOI: 10.17950/ijset/v4s3/322

\section{CITATIONS}

6

3 authors:

2. Ayobami Busari

Covenant University Ota Ogun State, Nigeria

42 PUBLICATIONS 40 CITATIONS

SEE PROFILE

Abayomi Emmanuel Modupe

Landmark University

17 PUBLICATIONS 21 CITATIONS

SEE PROFILE
READS

38

Owolabi A.O

Federal University of Technology, Akure

12 PUBLICATIONS 22 CITATIONS

SEE PROFILE

Some of the authors of this publication are also working on these related projects:

Project Green Highway and Pavement Construction View project

COMPRESSIVE STRENGTH ANALYSIS OF CONVENTIONAL DESIGN CONCRETE MIX RATIO; 1:2:4 AND NON-CONVENTIONAL CONCETE MIX RATIO; 1:3:3 FOR THE CONSTRUCTION INDUSTRY IN NIGERIA View project 


\title{
Modelling the Effect of Income and Car Ownership on Recreational Trip in Akure ,Nigeria
}

\author{
Busari Ayobami Adebola $^{a}$, Owolabi Adebayo ${ }^{b}$, Modupe Abayomi Emmanuel $^{c}$ \\ ${ }^{a}$ Department of Civil Engineering, Covenant University,Canaanland,Ota. \\ ${ }^{b}$ Department of Civil Engineering, Federal University Of Technology, Akure \\ ${ }^{c}$ Department of Civil Engineering, Landmark University,Omu-Aran \\ ayobami.busari@covenantuniversity.edu.ng
}

\begin{abstract}
The effect of income and car ownership on recreational trip pattern in the study area was analysed, focusing on the frequency of trips, modal choice and the land use pattern. It is an attempts to extend research on travel characteristics and behaviour to cities of the developing world with focus on Akure metropolis.
\end{abstract}

Keywords: Transportation planning, Trip pattern, Recreational Trip, Frequency of trip, Per Capita Trip.

\section{Introduction}

The significance of mobility in our daily endeavor is gigantum without which basic needs would not be accomplished. As wonderful as the role of transport maybe in our daily activities, it has been observed to have caused innumerable problems to the society at large ..In year 2002, Ogunsanya observed and confirmed how transport had built cities over the years in some urban areas in Nigeria and how it has gradually destroyed them. This research is aimed at analyzing the relationship between income and car ownership on trips in Akure, Nigeria. It is an attempt to extend research on travel characteristics and behaviour to cities of the developing nation in which Akure is not an exception

Car ownership is mainly used as an exogenous variable in addition to spatial and socio-economic variables, to explain travel behavior( Schwanet et al 2002.)

In high density areas people tend to travel shorter distances and they spend less time travelling on average ( (Kitamura et al 1997 Schwanen et al,2004 Stead, 2001). The increase in demand and purchase of vehicle is closely related to population growth and urbanization.

How income and car ownership affects both work and recreational trip have not been prevalently studied in Akure. Generalized version of how income and car ownership affects trips has been done but it has not been specifically considered in Akure, Nigeria. In this study travel behaviour has been comprehensively looked into by focusing on car ownership, income, and socio-economic factors that influence trip making. The land use configuration of the study area was also considered.Models were developed instead of a simple curve or chart, the models developed are useful tools for transportation planning.

The number of trips generated increases both with increasing income and car ownership, therefore both factors are important in determining the number of trips( kockman, 1997). Van Acker and Witlox, 2010 point out that accessibility is negatively associated with car ownership. The same author also observes that households living in neighborhoods that are easily accessible by public transport tend to make more trips by public transport. Assessment of travel demand is necessary in forecasting the trip generation of a city Owolabi 2009 states that, travel demand forecasting process is a fundamental operation within any urban transport planning exercise.

\section{Methodology \\ Strategy for data collection in the study area \\ Sampling Procedure and Data Collection}

Akure metropolis was divided into Six zones according to its land use configuration .This is to make collection, sorting and extraction of data accurate. The zones are; High density Residential zone, Medium density Residential zone , Low density Residential zone,, Commercial and Military density residential Zones.

Akure metropolis has a population of 360,268 (Nigeria Population Commission, 2006)).This consists of 178,672 (49.59\%) male and 181,596 (50.40\%) female. Data were collected using a sample size of 1 in 15 dwelling units, this was expanded for the population size of 360,268 persons as suggested by O' Flaherty (1974) and Salter (1989) and Bureau of Public Road (1954).

Data on income and car ownership of Akure metropolis were collected through domiciliary information gathering technique with the aid of a comprehensive questionnaire which was distributed and administered in all zones based on the land use configuration. This was supported by Public Use Data from National Population Commission (information on some demographic characteristics). Data on daily and weekly trips, Demographic and Socio- economic characteristics were collected which are:

Socio-Economic information: Occupation, Professional Status, Income, No of vehicles Owned, Type of vehicle owned, Cost of buying the car, and Maintenance records.

Information on trips: Type of trips, Time of making the trip, Purpose of trip, Modal choice, Trip distance, Cost of trip etc.

This analysis was based on trips of persons aged 18 years and older. These persons were considered to undertake trips relatively independently. Moreover the legal age of obtaining a license is 18 years in Nigeria. Therefore persons aged 18 or older have a potentially larger choice set of travel modes than younger persons. The study was limited to intra city trips. 


\section{I.JSET}

\section{Data Analysis}

The study analyzed the effect of income, car ownership, socioeconomic factors and demographic factors on recreational trips. The data was analyzed with the use of statistical computer software such as SPSS VERSION 16 and Ms-Excel. A linear regression model was calibrated to show the relationship between income, car ownership on recreational trips.

\section{Results and Tables}

Linear Regression Model on the Effect of Income and Car Ownership on Recreational Table 1:

\begin{tabular}{|l|l|l|l|l|l|}
\hline \multirow{2}{*}{\multicolumn{1}{c|}{}} & \multicolumn{2}{|c|}{$\begin{array}{c}\text { Unstandardized } \\
\text { Coefficients }\end{array}$} & $\begin{array}{l}\text { Standardized } \\
\text { Coefficients }\end{array}$ & \multirow{2}{*}{ T } & \multirow{2}{*}{ Sig. } \\
\cline { 2 - 6 } & $\mathrm{B}$ & Std. Error & Beta & & \\
\hline (Constant) & 1.483 & 0.495 & & 2.997 & .003 \\
\hline income1 & .721 & 0.124 & 0.404 & 5.736 & .000 \\
\hline noofCars1 & -.661 & -0.190 & 0.245 & -3.475 & .001 \\
\hline
\end{tabular}

Based on economic and statistical criterion, the relationship between income and car ownership on recreational trip is given by the semi log function in equation 1

$$
\begin{gathered}
\mathrm{Y}=\mathrm{B}_{0}+\mathrm{B}_{1} \mathrm{X}_{1}+\mathrm{B}_{2} \mathrm{X}_{2}+\mathrm{e}_{1} 1 \\
\text { Equation } 1
\end{gathered}
$$

\section{MULTIPLE REGRESSION RESULTS FOR INCOME} AND NUMBER OF CARS TRIP

The Outcome, Y Variable, which is Recreational trip generated in the six zones and Predictor $\mathrm{X}$ Variable (income and car ownership) are imputed, and checked for possible error.The coefficients generated are fitted in above are fitted to give :

$Y=1.483+0.72 \ln X_{1}+0.661 \ln X_{2}$

Equation 2

Variable description:

$\mathrm{Y}=$ Recreational trips,

$\mathrm{X}_{1}=$ income,

$\mathrm{X}_{2}=$ no of cars (car ownership)

Table 2: ANOVA

\begin{tabular}{|l|l|l|l|l|l|}
\hline Model & $\begin{array}{l}\text { Sum of } \\
\text { Squares }\end{array}$ & Df & $\begin{array}{l}\text { Mean } \\
\text { Square }\end{array}$ & F & Sig. \\
\hline Regression & 156.161 & 2 & 78.080 & 21.841 & $.000^{\mathrm{a}}$ \\
\hline Residual & 564.833 & 158 & 3.575 & & \\
\hline Total & 720.994 & 160 & & & \\
\hline
\end{tabular}

From equation 1 the two variables; income and number of cars (car ownership) were being tested in estimating the degree of relationship on recreational trips, income alone was found to be a significant variable positively affecting recreational trip of respondents in the study area.

\section{Frequency of trip}

A linear relationship exist between income and recreational trip (Equation 1), the high income group embark on more recreational trip that the low income group, this can be buttressed by figure 1 and Table 4 .

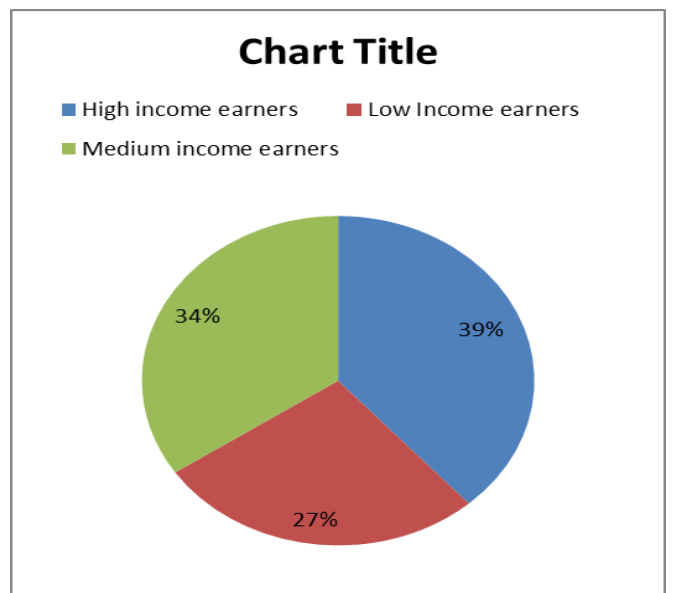

Figure 1: Relationship between Income Frequency of Recreational Trip

Table 3: Per Capita Recreational Trip Based on Land Use

\begin{tabular}{|l|l|l|l|l|}
\hline & $\begin{array}{l}\text { No of } \\
\text { persons }\end{array}$ & $\begin{array}{l}\text { No of } \\
\text { trips }\end{array}$ & $\begin{array}{l}\text { Weekly } \\
\text { trips } \\
\text { per } \\
\text { capital }\end{array}$ & $\begin{array}{l}\text { Daily } \\
\text { trips per } \\
\text { capital }\end{array}$ \\
\hline Low Density & 2882 & 24796 & 8.6 & 2.2 \\
\hline $\begin{array}{l}\text { High Density } \\
\text { Zone }\end{array}$ & 6004 & 87963 & 14.65 & 1.2 \\
\hline $\begin{array}{l}\text { Medium } \\
\text { Density Zone }\end{array}$ & 3602 & 55832 & 15.5 & 2.09 \\
\hline $\begin{array}{l}\text { Educational } \\
\text { Zone }\end{array}$ & 7205 & 60814 & 8.84 & 1.26 \\
\hline $\begin{array}{l}\text { Commercial } \\
\text { Zone }\end{array}$ & 3842 & 38280 & 9.96 & 1.432 \\
\hline Military Zone & 480 & 3966 & 8.2 & 1.17 \\
\hline
\end{tabular}

This research established the fact that though income is a positive factor affecting the total volume of recreational trip car ownership has an inverse effect on recreational trip (equation 2) ,despite the fact that the high income earners account for the highest percentage car ownership (Figure 2 ) they patronize other modes for recreational trip. From (Figure 3) shows the factors responsible for this.

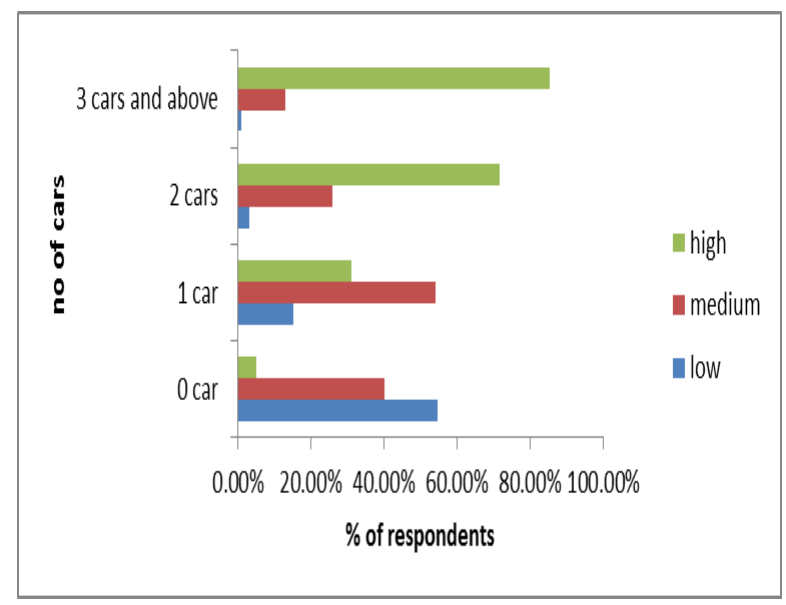

Figure 2: Relationship between income and car ownership 


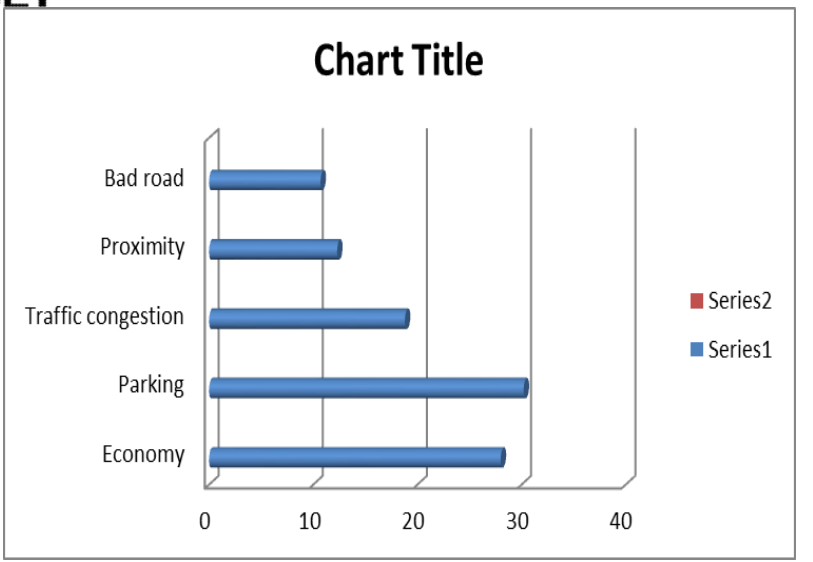

Figure 2: Factors Affecting the Use of Cars for Recreational Trip

\begin{tabular}{|l|l|l|l|}
\hline Modal choice & $\begin{array}{l}\text { Low income } \\
\text { earners }\end{array}$ & $\begin{array}{l}\text { Medium } \\
\text { income } \\
\text { earners }\end{array}$ & $\begin{array}{l}\text { High } \\
\text { income } \\
\text { earners }\end{array}$ \\
\hline Private car & $5.9 \%$ & $14.40 \%$ & $12.7 \%$ \\
\hline Taxi & $41.6 \%$ & $30.20 \%$ & $32.10 \%$ \\
\hline Walk & $24.70 \%$ & $18.30 \%$ & $20.30 \%$ \\
\hline Bus & $3.40 \%$ & $26.40 \%$ & $14.0 \%$ \\
\hline Motorcycle & $21.3 \%$ & $10.40 \%$ & $21.60 \%$ \\
\hline Official & $3.10 \%$ & $0.3 \%$ & $0.07 \%$ \\
\hline
\end{tabular}

Table 4: Modal Choice Used

Proposed Model Application for Transportation
Planning

\section{CONCLUSION AND RECCOMMENDATION}

This study established the fact that modal choice may not necessarily be a function of household income. If an effective and efficient public transport is not put in place the study area the foreseeable future may start encountering the scarcity of some modes especially taxi. The model can be readily used to predict how changes in car ownership and income can affect recreational trip.
01 March. 2015

\section{REFERENCES}

i. Bureau of Public Roads (1954), "Conducting a Home Interview: Origin and Destination survey, "Procedure Manual 2B, U.S Public Administration Services.

ii. Chen Guojing (2012) Journal of Highway and Transport Research and Development.

iii. Ho,Hing-Lun (1999),The inter-relationship between household income and trip generation with particular reference to rail transportation planning

iv. Kitamura, Mokhtarian, laidet, (1997).A micro-analysis of land use and travel in five neighborhood in the san Francisco Bay Area. Transportation 24(2), 125-158.

v. Kockelman,K.,M. (1977). Travel behaviour as function of accessibility, land use mixing, and land use balance. Evidence from San Francisco bay Area. Transportation Research record 1607,116125 .

vi. National Population Commission (2006).Public use data, National Population Commission, Abuja.

vii. O'flaherty C. A. (1974), Highways and Traffic, $2^{\text {nd }}$ Edition, London: Edward Arnold

viii. Ogunsanya A.A (2002)'"Maker and breaker of cities the fiftyninth inaugural lecture presented at theUniversity of Ilorin,Ilorin.

ix. Owolabi A. (2009). Para transit modal choice in Akure, Nigeria- Application of Behavioral models .pg. 54-58.Journal of Transportation.

x. Owolabi A.O. (2010). Trip pattern in Akure, Nigeria; A Landuse Analytical Approach Journal of transportation management USA Vol.21 No 2A pg. 63-71.

xi. Schwanen, T., Dieleman, F. M., (2004.) The impact of metropolitan structure on commute behavior in the Netherlands' multilevel approach. Growth and change 35(3), 304- 333.

xii. Stead., D,( 2001). Relationships between land use, socioeconomic factors and travel patterns in Britain, Environment and planning B28 (4), 499-528.

xiii. Van Acker,V.\& Witlo,F (2010). Car ownership as a mediating variable in car travel behavior research using a structural equation modeling approach to identify its dual relationship. Journal of transport Geography 18(1), 65-74. 